Joumal of Islamic Studies and Humanities

Vol. 3, No. 1 (2018) 79-102,

DOI: http://dx.doi.org/10.21580/jish.31.2936

\title{
PANDANGAN KEAGAMAAN PELAKU BOM BUNUH DIRI DI INDONESIA
}

\author{
Herlina Nurani ${ }^{1}$ dan Ahmad Ali Nurdin ${ }^{2}$ \\ Univesitas Islam Negeri Sunan Gunung Djati Bandung, Indonesia ${ }^{12}$ \\ nuranienci@gmail.com¹ nurdinster@gmail.com²
}

\begin{abstract}
This journal discusses most of the religious discussions launched in Indonesia. This research is library research. Is the result of being found first, understanding the religious texts textually. Second, there are differences of opinion that influence the text that improves development that accommodates modernization theories, thereby increasing disappointment with the government. Third, the existence of understanding as jihad is a holy war against unbelievers because it considers the government system in Indonesia to be changed based on the justice of their religious understanding.
\end{abstract}

Keyword: globalization; religion; radicalism; jihad;

\begin{abstract}
Abstrak
Jurnal ini menelusuri tentang sebagian pandangan keagamaan pelaku bom bunuh diri di Indonesia. Penelitian ini adalah library riset. Adapun hasil yang ditemukan pertama, pemahaman nash-nash agama secara tekstual. Kedua, adanya sikap protes yang mempengaruhi pemahaman teks serta kegagalan pembangunan yang mengakomodasi teori-teori modernisasi, sehingga terjadinya kekecewaan terhadap pemerintah. Ketiga, adanya paham bahwa jihad adalah perang suci sebagai perang untuk melawan orang kafir karena menganggap sistem kepemerintahan di Indonesia harus dirubah berdasarkan kebenaran pemahaman keagamaan mereka.
\end{abstract}

Kata Kunci : globalisasi; agama; radikalisme; jihad;

ISSN 2527-8401 (p) 2527-838X (e)

(C) 2018 JISH Pascasarjana UIN Walisongo Semarang

http://journal.walisongo.ac.id/index.php/jish 
Pemahaman Keagamaan Pada Kasus Bom Bunuh Diri

\section{Pendahuluan}

Globalisasi adalah suatu pandangan masyarakat yang merujuk pada sistem perkembangan tatanan kehidupan, salah satu contohnya yaitu perkembangan sistem teknologi yang sudah sangat canggih. ${ }^{1}$ Pada dasarnya pertumbuhan arus globalisasi ini tentunya memberi dampak terhadap kehidupan manusia dimanapun. Dampak yang dihasilkan dari globalisasi itu bersifat positif ataupun negatif. Sisi positifnya adalah manusia mampu mendapatkan kemajuan di bidang teknologi dan komunikasi. Segala informasi yang di inginkan akan bisa didapatkan saat itu pula, tanpa mempersoalkan jarak tempuh yang sedemikian jauh. Sisi negatifnya adalah globalisasi ini terlalu mengedepankan aspek modernitas atau hal-hal yang mengarah kepada pemikiran kebergantungan kepada sains. Manusia akan sangat bergantung kepada hal yang bersifat material, atau nampak. Sehingga kepercayaan terhadap segala sesuatu yang gaib (agama) akan tergantikan. Sehingga ini menjadi persoalan dikalangan ilmuan dimana ada pernyataan bahwa agama tidak akan lagi hadir di hati masyarakat karena akan tergantikan oleh sains. ${ }^{2}$

Menurut Majid Tehranian kebangkitan agama ditunjukan karena adanya sikap kritis terhadap modernitas yang tidak mampu menyelesaikan persoalan batiniah. Contohnya manusia kecewa terhadap kehidupan yang bersifat modern yaitu hanya berdasarkan akal yang rasional. Sementara manusia mengalami kegalauan, kesedihan, persaan tidak tenang, merasa lemah, juga sering gagal. Untuk mengatasi hal tersebut manusia kembali kepada agama. ${ }^{3}$

1 Yusuf Al-Qardhawi, Islam Dan Globalisasi Dunia (Bandung: Pustaka Al-Kautsar, 2001), 12.

${ }^{2}$ Daniel L. Pals, Dekonstruksi Tujuh Dekonstruksi Kebenaran (Yogyakarta: IRCiSoD, 2001), 48.

${ }^{3}$ Majid Tehranian, "Globalization and Religious Resurgence : An Historical Perspektive” Vol. 97, no. No. 7 (2001): 391. 
Herlina dan Ahmad

Contohnya yaitu menyerahkan diri sepenuhnya kepada agama yang mereka yakini. Hal ini dibuktikan dengan pembelaan manusia untuk agama dengan adanya kasus bom bunuh diri yang mengatas namakan jihad. Jihad yaitu upaya pembelaan Tuhan yang dilakukan oleh manusia. Kasus bom bunuh diri ini terjadi berdasarkan dua faktor. Pertama faktor agama, dan kedua faktor politik. yang dimaksud faktor agama adalah bom bunuh diri ini dilakukan oleh orang yang betul-betul taat kepada Tuhannya, dan rela mati dijalan-Nya.

Pemahaman tersebut didapatkan dari guru agama yang mereka percaya. Agama dijadikan alat politik oleh pihak tertentu, yaitu pemahaman berupa bentuk kebencian terhadap sistem pemerintah, atau perebutan hak kepemilikan. Hal ini sengaja diberikan sebagai proses doktrinasi oleh orang-orang yang dianggap suci atau pandai dalam ilmu agama. kasus bom bunuh diri di Indonesia bukanlah hal baru, namun sudah terjadi saat adanya kasus bom Bali pada 12 Oktober tahun 2002, bom Bali 2005, bom hotel JW Mariott Jakarta 2003, bom Kalimalang 2010, bom Mesjid Cirebon 2011, bom Sarinah 2016, hingga bom Kampung Melayu Jakarta 2017.

Tulisan ini mencoba menjawab beberapa pertanyaan yang mendasar yaitu: Apa itu globalisasi? Apa itu pemahaman keagamaan? Lalu bagaimana Pengaruh globalisasi terhadap pemahaman keagamaan? Dan bagaimana bom bunuh diri bisa terjadi di Indonesia? Adapun metode yang digunakan adalah metode deskripsi analisis. yang menggambarkan keberagamaan mayarakat yang bersifat Fundamental, dan sikap tersebut memunculkan sikap anti pluralisme di Indonesia yang dibuktikan dengan aksi bom bunuh Diri.

\section{Agama dalam Berbagai Perspektif}

Perspektif tentang Agama tentu tidak sama, didalamnya terdapat perbedaan-perbedaan dalam setiap penafsiran, sehingga 
Pemahaman Keagamaan Pada Kasus Bom Bunuh Diri

penafsiran dan variasi dalam memahami agama tentu disesuaikan dengan selera peminat yang mengkaji. Misalnya bagi para sosiolog, mereka melihat agama dan korelasinya dengan masyarakat serta interaksi diantar keduanya, sedangkan dunia antropologi memandang agama melalui pengungkapan simbol-simbol kepercayaan religius pada masyarakat, sedangkan bagi kaum psikolog lebih menitik beratkan pada dimensi pengalaman keagamaan para pemeluknya. ${ }^{4}$

Namun definisi agama dari sudut pandang ilmu lain yaitu ilmu etimologi bahasa, atau penyusuran makna akar kata. "Agama" bila kita telusuri dari makna akar katanya berasal dari bahasa Sansekerta yang terdiri dari dua susunan kata yaitu "a" yang berarti tidak, dan "gama" yang berarti kacau, dengan demikian, definisi keseluruhan dari agama adalah aturan atau tatanan untuk mencegah kekacauan dalam kehidupan manusia. ${ }^{5}$ Sedangkan dalam bahasa Inggris dikenal dengan kata "Religion" yang berasal dari kata Latin Relegere yang artinya membahas ulang, dan "religere" yang berarti mengikat erat-erat, jadi kesimpulannya agama merupakan Pengikat kehidupan manusia yang diwariskan secara berulang dari generasi kegenerasi. ${ }^{6}$

Adapun agama dari sudut pandang psikologi dan sosiologi pendefinisian agama melalui jalan deskriptif telah kita bahas di atas baik melalui sudut pandang Psikologi, Sosiologi atupun Etimologi bahasa, tetapi masih ada satu cara untuk mendefinisikan agama melalui jalan praktis yaitu mengungkap definisi agama melalui metode paradigmanya, maksudnya adalah dengan menunjuk langsung terhadap contoh konkretnya, seperti mengarah langsung pada bentuk-bentuk agama yang kita kenal selama ini, sehingga terhadap pernyataan "Apa itu agama" metode ini akan

\footnotetext{
${ }^{4}$ Hendropuspito D, Sosiologi Agama (Yogyakarta: Kanisius, 2001), 21.

${ }^{5}$ Wajowasito, Kamus Bahasa Indonesia (Jakarta: Shinta Darma, 1972), 4.

${ }^{6}$ Permata, Metodologi Studi Agama, n.d., 62.
} 
Herlina dan Ahmad

memberikan jawaban "agama" adalah seperti Hindu, Budha, Kristen, katolik, Islam, Khonghucu dan sebagainya. Nurcholis Majdid (Cak Nur) dalam bukunya Passing Over menerangkan bagaimana cara yang mudah untuk memahami apa itu agama dan bagaimana bentuk agama di masyarakat.

Menurutnya Sebenarnya dalam memahami agama seperti kita memahami sisi dua mata uang koin, dua penampakkan yang berbeda namun maknanya sama. Menurut Cak Nur melihat agama dari dua kategori yaitu isotoris dan eksoteris.

1. Makna agama secara Esoteris / Horizontal

Memahami agama secara esoteris atau horizontal yaitu, hubungan individu dengan Tuhannya, bersifat privat (pribadi), karena bersifat privat sehingga yang berhak mengetahuinya hanyalah individu dengan Tuhannya saja. Orang lain tidak ada yang tahu dan tidak berhak ikut campur, ini kaitannya dengan ganjaran. Ganjaran bisa dikatakan sebuah nilai atau poin yang diperoleh seseorang dari apa yang dia lakukan. Seperti contohnya: syahadat, sholat, zakat, puasa, dan ibadah haji.

2. Makna agama secara Eksoteris / Vertikal

Pemahaman agama secara eksoteris adalah pemahaman agama yang berhububgan dengan hubungan anatara manusia dengan Tuhan dan manusia lainnya. Ini biasanya dapat diketahui oleh publik karena perbuatannya nyata dan nampak dengan keadaan yang ada di masyarakat, karena selain berhubungan dengan Tuhan juga berhubungan dengan manusia lainnya. Dari sini biasanya akan menimbulkan sebuah konflik antar individu dan sesamanya. Konfik tersebut bisa muncul dari diri sendiri karena ada faktor luar yang mempengaruhinya ada juga konflik yang memang bersumber dari luar. Salah satu faktor munculnya konflik tersebut adalah dengan adanya paksaan yang

${ }^{7}$ Komarudin Hidayat, Passing Over: Melintas Batas Agama, ed. Ahmad Gaus (Jakarta: Gramedia, 1998), iii.

Vol. 3, No. 1 (2018) 
Pemahaman Keagamaan Pada Kasus Bom Bunub Diri

menjadikan seseorang bergejolak dan akhirnya mengundang konflik. Contoh dari pemahaman agama secara eksoteris adalah semua tindakan yang bersifat sosial, seperti contoh pengajian, partai politik keagamaan, dan organisai-organisasi sosial, agama dll. yang marak di masyarakat. Contohnya hal-hal yang mengarah kepada aspek sosial, yaitu hubungan manusia dengan manusia yang mengarah bukan pada aspek saling curiga sehingga menimbulkan konflik, akan tetapi mengarah kepada nilai persatuan umat manusia, dengan cara berdialog.

Dialog bukanlah sesuatu yang negatif, bukan hanya komunikasi, bukan memberikan jawaban atas apa yang dihadapi pihak lain; bukan mencari permufakatan dari pihak lain; bukan mencari kompromi. Boleh jadi mufakat, namun itu bukan tujuannya. Tujuan dialog adalah sesuatu yang positif yaitu, memberi informasi dan nilai-nilai yang dimiliki, lalu membantu pihak lain mengambil keputusaan yang dapat dipertanggungjawabkan. Tak peduli apakah keputusan itu "ya" atau "tidak", karena keduanya sama pentingnya. Jadi dalam dialog sikap berbeda-beda dari peserta dihargai itulah yang dimaknai musyawarah.

Di sini tidak ada soal "kalah" atau "menang". Hal terpenting adalah tumbuhnya saling pengertian yang objektif dan kritis; menumbuhkan kembali alam kejiwaan yang semula tertutup oleh tirai pemisah karena tiadanya saling pengertian kepada alam dan bentuk kejiwaan yang otentik dan segar, yang memungkinkan dua belah pihak mengembangkan diri sendiri sebagai pribadi yang sejati. Disadari atau tidak, manusia hanya dapat menjadi diri sendiri dalam alam perjumpaan personal dimana ada penyapaan dan tanggapan. Dialog yang baik akan mengarah kepada 
terciptanya pertemuan pribadi-pribadi yang bentuk konkritnya berupa kerja sama demi kepentingan bersama. ${ }^{8}$

Berbeda halnya ketika agama dilatar belakangi karena truth claim yang di gunakan sebagai alat kebencian, sehingga terjadi konflik atas nama agama. konflik tersebut dipicu oleh sikap radikalisme. Radikalisme tidak muncul dari ruang hampa. Mengikuti faham kaum fakta sosial, bahwa radikalisme adalah sebuah gerakan yang terkait atau disebabkan oleh Perilaku radikal adalah perilaku yang ditampilkan oleh orang-orang yang ingin melakukan perubahan dengan menjebol seluruh sistem dan strukturnya sampai ke akar-akarnya. Perubahan dimaksud adalah perubahan yang dilakukan secara mendasar dan cepat baik struktur dan konten. Yang diinginkan adalah penjebolan terhadap status quo dan menggantinya dengan yang baru yang dianggapnya benar. Seringkali di dalam tindakannya menggunakan cara-cara yang keras. Terutama kekerasan yang bercorak aktual.

Menurut Emile Durkheim bahwa agama merupakan alat perekat sosial, dimana agama memiliki potensi integrasi bagi masyarakat yang memiliki emosi keagamaan yang sama. Solidaritas sosial menjadi hal yang sangat diutamakan, yang menjadi dasardasar struktur kehidupan yang menggerakan kelompok.

Melford E Spiro yang mengatakan agama sebagai "Sebuah institusi berpola budaya yang berhubungan dengan wujud-wujud supra-manusiawi yang dipostulatkan secara budaya". Atau definisi agama menurut Milton Yinger yang merumususkan agama sebagai "Sebuah sistem kepercayaan dan prilaku, yang dengannya sekolompok manusia bergulat dengan masalah kehidupan manusiawi yang bersifat ultima". Ataupun definisi lain yang ditawarkan oleh J.B. Pratt yang mengusulkan agama sebagai "Sikap yang serius dan sosial dari individu-individu atau komunitas-

\footnotetext{
${ }^{8}$ Hidayat, 42.

${ }^{9}$ Pals, Dekonstruksi Tujuh Dekonstruksi Kebenaran, 147.
} 
Pemahaman Keagamaan Pada Kasus Bom Bunuh Diri

komunitas kepada satu atau lebih kekuatan yang mereka anggap memiliki kekuasaan tertinggi terhadap kepentingan dan nasib mereka". ${ }^{10}$

Sedangkan dari aspek Antropologi yaitu teori Clifford Geertz yang memandang agama sebagai: ${ }^{11}$

1. Sebuah sistem simbol-simbol yang berlaku untuk menetapkan suasana hati dan motivasi-motivasi yang kuat, yang meresapi dan yang tahan lama dalam diri manusia dengan merumuskan konsep-konsep mengenai suatu tatanan umum eksistensi.

2. Membungkus konsep-konsep ini dengan semacam pancaran faktualitas, sehingga suasana hati dan motivasi-motivasi itu tampak khas secara realita. Artinya praktik atau kegiatan keagamaan mampu oleh masyarakat atau kelompok mampu menggabarkan aspek teologi atau hubungan Tuhan dengan Manusia.

\section{Hubungan Agama dan Globalisasi}

Agama sebagai bagian dari identitas primordial ternyata mengalami tekanan-tekanan dari arus globalisasi. Namun berbeda dengan sistem-sisten lain, respon agama terhadap globalisasi membentuk diskursus yang menarik untuk diperdebatkan. Setidaknya ada tiga bentuk respon agama terhadap proses globalisasi dan segala efek yang dibawanya, yaitu bersikap resisten, akomodatif, dan kritis. ${ }^{12}$ Dalam kasus Islam misalnya, Johan Meuleman menyebut adanya tiga bentuk respon umat Islam untuk

10 Permata, Metodologi Studi Agama, 15.

${ }^{11}$ Clifford Geertz, Kebudayaan \& Agama (Yogyakarta: Kanisius, 1992),

5.

12 Peter Beyer, Religion and Globalization, n.d., 3. 
Herlina dan Ahmad

merespon perkembangan globalisasi dan modernisme, yaitu sikap pelarian ke dalam, pelarian ke luar dan keterbukaan yang kritis. ${ }^{13}$

Salah satu bentuk dari sikap resisten agama terhadap globalisasi adalah sikap untuk melakukan pelarian ke dalam dan menggali kembali nilai-nilai agama untuk dijadikan sebagai sistem tandingan menghadapi sistem-sistem yang dilahirkan oleh arus modernisasi dan globalisasi. Sikap resisten ini kemudian membangkitkan lahirnya gerakan-gerakan fundamentalisme keagamaan, yaitu sebuah gerakan yang berusaha memahami agama secara rigid dan kaku (tekstual) serta menutup diri terhadap berbagai perkembangan modern yang ditopang oleh kekuasaan rasionalitas. Hal itu yang dialami oleh umat Islam.

Pengaruh globalisasi terhadap kehidupan manusia sangat beragam dan kompleks. Globalisasi dalam kasus tertentu dapat meruntuhkan nilai dan identitas budaya dan dalam kausailitasnya dapat membangkitkan nilai dan identitas keagamaan yang diwarisinya. Kadang-kadang berdasarkan kondisi tertentu agama dapat memainkan peran dalam menolak dominasi global. ${ }^{14}$ Globalisasi menimbulkan perubahan dalam suatu agama. Dalam konteks ini, respons agama terhadap fenomena tersebut berbedabeda sesuai dengan karakteristik teologis dan doktrinalnya.

Pertama, di Indonesia aspek politik sangat berpengaruh, yaitu munculnya fundamentalisme dan radikalisme yang disebabkan oleh tekanan politik penguasa terhadap keberadaannya. Di beberapa belahan dunia, termasuk Indonesia, fenomena radikalisme atau fundamentalisme muncul sebagai akibat otoriterisme. Dalam kasus Orde Baru, Negara selalu membabat habis yang diidentifikasi sebagai gerakan radikal. Baginya,

${ }^{13}$ Johan Meuleman, Sikap Islam Terhadap Perkembangan Kontemporer Dalam Mukti Dkk, Agama Dalam Perkumpulan Masyarakat Modern (Yogyakarta: Tiara Wacana, 1998), 22.

${ }^{14}$ Adnan Aslan, Menyingkap Kebenaran: Pluralisme Agama Dalam Filsafat Islam Dan Kristen (Bandung: Alifya, 2004), 26. 
Pemahaman Keagamaan Pada Kasus Bom Bunuh Diri

radikalisme adalah musuh nomor satu dan dijadikan sebagai common enemy melalui berbagai media transformasi. Radikalisme kiri dan kanan sama saja. Radikalisme kiri seperti Gerakan New Left, yang pernah berkembang di Indonesia di tahun 1980-an dan terus memperoleh momentum di tahun-tahun 1990-an melalui Partai Rakyat Demokratik (PRD) merupakan eksponen organisasi yang dianggap sebagai musuh negara. Begitu kerasnya tekanan terhadap gerakan kiri radikal ini, maka banyak tokohnya yang ditangkap, disiksa dan bahkan ada yang hilang tidak tentu rimbanya. Sikap radikal muncul karena bentuk protes terhadap kebijakan penguasa. Oleh karena itu kalangan ekstrimis menggunakan kata Jihad untuk melawan sistem pemerintahan.

Pada masa orde baru yang paling menonjol adalah isu Komando Jihad, di pertengahan tahun 1980-an. Banyak tokoh Islam yang diidentifikasi sebagai pemimpin atau anggota Komando Jihad yang ditangkap dan ditahan. Usaha untuk memberangus gerakan-gerakan radikal Islam itupun terus berlangsung sampai periode munculnya Ikatan Cendekiawan Muslim Indonesia (ICMI) di pertengahan tahun 1990-an. ${ }^{15}$

Di era Reformasi terjadi berbagai kekerasan atas nama agama tidak serta merta menyebabkan kemunduran terhadap organisasinya. Jika terjadi kekerasan agama, seperti peledakan, penyerangan dan sebagainya, maka cukup aktor-aktornya yang ditahan, diadili atau dihukum sesuai dengan tindakannya. Hal ini sangat berbeda dengan masa Orde baru, yang tidak hanya penangkapan dan pemberian hukuman terhadap aktornya tetapi juga pelarangan terhadap organisasinya.

Kedua, Munculnya berbagai gerakan Islam yang berkonotasi radikal, seperti Hizbut Tahrir Indonesia, Majelis Mujahidin

${ }^{15}$ Abdul Azis Thaba, Islam Dan Negara Dalam Politik Orde Baru (Jakarta: Gema Insani Press, 1995), 1. 
Herlina dan Ahmad

Indonesia, Gerakan Salafi, Lasykar Jundullah, Lasykar Jihad, Gerakan Islam Ahlu Sunnah wal Jamaah dan berbagai gerakan keagamaan bercorak lokal adalah sebuah potret tentang merebaknya geraan-gerakan keagamaan di tengah euphoria keterbukaan, demokratisasi dan hak asasi manusia. Selanjutnya kegagalan rezim sekuler dalam merumuskan kebijakan dan mengimplematasikannya di dalam kehidupan masyarakat. Rezim sekuler di negara-negara berkembang yang kebanyakan mengadopsi system kapitalisme ternyata gagal dalam mengimplementasikan kebijakannya di tengah ketidakpastian ekonomi dunia. Kegagalan pembangunan yang mengakomodasi teori-teori modernisasi. ${ }^{16}$ Hal tersebut berdampak kepada ketidakpercayaan masyaraat terhadap model pembangunan yang diadopsi dari pengalaman-pengalaman Negara barat tersebut. Krisis ekonomi yang berkepanjangan di Negara-negara berkembang di antaranya disebabkan oleh kesalahan di dalam penerapan teori pembangunan yang bertumpu kepada bantuan luar negeri. Dana pembangunan luar negeri yang seharusnya digunakan untuk pembiayaan pembangunan di dalam berbagai sektor ternyata juga dikorupsi.

Ada kesenjangan antara praktik pembangunan dengan kebijakan yang dirumuskan. Moralitas pembangunan yang nuruk seperti ini kemudian mengilhami munculnya gerakan-gerakan anti korupsi, kolusi dan nepotisme yang melanda kehidupan birokrasi dan masyarakat. Di tengah ketidakpercayaan ini, maka mucullah gagasan Islam sebagai alternative untuk solusi. Tidak salah jika orang melirik terhadap gerakan-gerakan yang memberikan janji perbaikan, melalui solusi Islam. Ketika Negara tidak lagi dapat mengatasi kemungkaran, maka tampillah mereka untuk memberantasnya. Maka, dilakukanlah gerakan-gerakan amar ma'ruf

${ }^{16}$ Arief Budiman, Teori-Teori Pembangunan Di Dunia Ketiga (Jakarta: Gramedia Pustaka Utama, 1994), 1.

Vol. 3, No. 1 (2018) 
Pemahaman Keagamaan Pada Kasus Bom Bunub Diri

nabi mungkar melalui cara dan mekanisme yang menurutnya absah. Tampillah di sini gerakan Islam garis keras yang melakukan tindakan menurut konstruksi sosialnya dan yang dianggapnya benar.

Ketiga, respon terhadap barat. Kebanyakan isu yang diangkat ke permukaan oleh kelompok ini adalah responnya terhadap apa pun yang datangnya dari barat. Isu tentang pluralsime, demokrasi dan bahkan hak asasi manusia adalah rekayasa barat untuk meminimalisasikan peran dan pengaruh Islam dalam kehidupan masyarakat. Semua ide tentang persoalan tersebut dikemas dengan konsep modernisasi dan sekularisasi. Modernisasi mempunyai anak kandung kapitalisme dan materialisme. Kapitalisme yang merupakan proses akumulasi modal didasarkan atas konsep individualisme yang dianggap bertentangan dengan konsep Islam tentang sistem masyarakat. Sedangkan materialisme yang menganggap bahwa materi adalah segala-galanya juga sangat bertentangan secara diametral dengan Islam. Apalagi sekularisasi yang bemakna pemisahan antara agama dan kehidupan dunia juga merupakan musuh Islam yang lebih menekankan kehidupan spiritual. Berbagai isu ini, mau tidak mau harus dilawan sebab akan menggerogoti kehidupan umat Islam secara umum.

Di tengah ketidak menentuan ini, muncul konsep globalisasi yang menihilkan batas geografis, budaya, sosial dan ekonomi. Makanya, apa yang terjadi di Negara-negara barat dalam waktu sangat singkat akan terjadi di belahan lain. Padahal, seperti moral permissiveness yang diimpor dari barat tentunya sangat bertentangan dengan ajaran Islam. Dalam keadaan banyaknya penyimpangan moral, perilaku dan tindakan-tindakan di dalam masyarakat, maka gerakan Islam ini menawarkan konsep kembali ke kehidupan masa lalu, al-salaf al-salih. Kehidupan ini ditandai dengan pengamalan Islam secara kaffah, dalam semua tataran 
Herlina dan Ahmad

kehidupan. Hukum harus didasarkan atas sistem syariah, ekonomi harus berbasis syariah, politik berasas syariah dan sebagainya.

Gerakan Islam Radikal sangat responsive terhadap apa saja yang datang dari dunia barat. Modernisasi dengan berbagai implikasinya adalah musuh besarnya. Melalui pergulatannya dengan sekularisasi yang permissiveness, maka visi dan misi utama adalah mengembalikan masyarakat ke dalam pangkuan Islam yang seluruh kandungan ajarannya mengatur kehidupan manusia secara total.

Modernisasi yang kebanyakan berdampingan dengan sekularisasi memang menempatkan agama dan tafsir agama ke dalam tempat yang terpinggirkan. Dunia agama yang penuh dengan keyakinan dan ritual untuk memuja dan memuji sesuatu yang sakral atau the other adalah tindakan yang tidak relevan dengan tuntutan modernisasi yang lebih bersearah dengan tindakan efektif dan efisien. ${ }^{17}$ Sekularisasinya lebih melihat ke dunia sekarang dari pada dunia akhirat. Yang sakral telah dianggap barang usang di tengah merebaknya kehidupan yang modern dan sekular.

Konsep fundamentalisme memang sangat problematic. Para teoretisi banyak berdebat tentang istilah ini. William Montgomery Watt menyatakan bahwa istilah fundamentalisme berasal dari kata di dalam Inggris kuno yang dikaitkan dengan orang-orang yang berpandangan bahwa al-Kitab harus diterima dan ditafsirkan secara harfiah. James Barr, menyatakan kaum fundamentalis adalah kelompok yang: Pertama, menekankan pada ketidaksalahan al-Kitab. Al-Kitab tidak mengandung kesalahan sedikitpun. Kedua, membenci secara mendalam terhadap teologi modern serta metode dan akibat-akibat yang ditimbulkannya. Ketiga, menganggap bahwa siapapun yang terlibat dengan gerakan teologi

${ }^{17}$ George Ritzer, Contemporary Sociological Theory (New York: Mc-Graw Hill Companies Inc, 1985), 1 dan periksa juga Malcolm Waters, Modern Sociological Theory. (London: Sage Publication, 1994).

Vol. 3, No. 1 (2018) 
Pemahaman Keagamaan Pada Kasus Bom Bunuh Diri

modern adalah bukan Kristen sejati. Robert N. Bellah dan William Liddle lebih suka menggunakan istilah Skripturalisme untuk menunjuk kepada gerakan keagamaan yang bercorak literalis atau tekstual. Ketika melihat Islam, maka Islam fundamentalis hakikatnya adalah kelompok yang melihat al-Qur'an dan al-hadits sebagai entitas teks yang tidak ada kesalahannya sama sekali, yang sempurna, yang datang dari Tuhan dan terhindar dari kemungkinan kritik.

Para penulis Islam juga bervariasi pandangannya tentang fundamentalisme. Roger Garaudy, dengan merujuk pada Kamus Larous kecil, dia menyatakan bahwa fundamentalisme adalah sikap mereka yang menolak menyesuaikan kepercayaan dengan kondisikondisi yang baru. Dan berdasarkan kamus Larous saku dinyatakan sikap pemikiran sebagian orang-orang Katolik yang membenci untuk menyesuaikan diri dengan kondisi kehidupan modern. Dalam kamus Larous besar, dinyatakan sikap stagnan dan membeku yang menolak seluruh pertumbuhan dan seluruh perkembangan. Fazlurrahman, lebih cenderung menggunakan istilah revivalisme untuk menunjuk kepada fenomena gerakan keagamaan yang cenderung kembali ke dalam ajaran lama. ${ }^{20}$ kelompok fundamentalisme yang menolak sikap kritis terhadap doktrin atau teks-teks keagamaan karena percaya bahwa penalaran manusia tidak akan bisa mencapai penafsiran yang memadai dan sesuai dengan teks tersebut. Kedua yaitu penolakan terhadap pluralisme yang merupakan prodak dari globalisasi atau modernitas yang dianggap mampu menggerogoti keimanan seseorang. ${ }^{18}$

Ada beberapa masyarakat yang menunjukan rasa intoleransi beragamanya sebagai bentuk protes kepada pihak yang tidak

18 Azumardi dkk Azra, Formulasi Ajaran Islam Jihad, Khihafah, Dan Terorisme (Jakarta: Mizan, 2016), 245.

92 
Herlina dan Ahmad

menegakan hukum Islam. salah satu contohnya kasus bom bunuh diri. Dengan sikap militan yang tinggi dan kadang-kadang dibumbui dengan sikap radikal, fundamentalisme muncul sebagai fenomena yang lahir seiring dengan laju globalisasi, bahkan sebagai bagian yang tidak terelakkan lagi dalam sistem global. Apakah ini yang disebut dengan fenomena "kebangkitan agama" di era global ataukah sebagai paradoks keagamaan kita tidak bisa begitu saja melakukan penilaian. Hanya barangkali yang bisa dikatakan adalah bahwa desakan globalisasi telah membangkitkan kerinduan orang akan nilai-nilai primordial dan merekatkan identitas kultural maupun keagamaan yang sudah sekian lama tercerabut dari akarnya.

Globalisasi yang memiliki cakupan yang luar biasa, diakui atau tidak telah memarjinalkan sendi-sendi masyarakat yang berakar pada tradisi-tradisi yang diilhami oleh nafas keagamaan. Maka kembali kepada sendi-sendi agama adalah alternatif yang mungkin untuk membendung laju globalisasi agar terjadinya keseimbangan.

Maksudnya adalah globalisasi dalam konteks ini bukan hanya dipahami sebagai sikap keterbukaan saja, tetapi juga tidak menyerahkan diri secara membabi buta kepadanya. Sikap yang di satu pihak sadar akan hal yang baik dan bermanfaat dari luar lingkungan tradisi sendiri dan senang menikmatinya, di lain pihak sadar akan nilai dan cita-cita sendiri dan mengendalikan hubungan dengan dunia luar atas dasar nilai dan cita-cita itu. Pemikiran yang diajukan sehubungan dengan sikap yang ketiga inilah adalah sebuah kesadaran bahwa modernisasi di samping membawa dampak negatif ternyata juga banyak memiliki nilai-nilai positif yang dapat diambil sebagai rujukan dalam beragama.

\section{Bom Bunuh Diri di Indonesia}

Istilah fundamentalisme, radikalisme sering dicampuraduk dengan terorisme. Tak jarang juga istilah terorisme selalu dikaitkan 
Pemahaman Keagamaan Pada Kasus Bom Bunub Diri

dengan garakan-gerakan Islam. Meskipun di kalangan Kristen Protestan sendiri, sesungguhnya makna fundamentalisme adalah ejekan. Karena selalu dikaitkan dengan para tokoh penginjil yang literalis atau skripyuralis, yang memiliki kepercayaan secara tekstual. Selain tekstual kelompok tersebut menolaknya sehingga dianggap statis dan ekstremis. ${ }^{19}$ Namun demikian, dalam wacana yang dikembangkan oleh dunia barat dan sekutunya, bahwa yang paling mendukung terhadap tindakan terorisme adalah Islam. Perilaku terror atau bom bunuh diri yang dilakukan oleh orang yang mengaku membela "Islam" sesungguhnya adalah hal tersebut harus dilihat kembali dari sudut pandang kasuistis.

Kasus bom Bali 12 Oktober 2002 yang menewaskan 182 orang (kebanyakan warga Negara asing) dan ratusan yang lukaluka, maka peristiwa ini menandai fase yang baru gerakan terorisme yang dilabelkan kepada agama. yaitu prilaku teror ini menandai adanya tindakan keagamaan yang berwajah keras, bersifat memaksa, mencelakai, menghancurkan peradaban dan tentu bertentangan dengan martabat dan harkat manusia yang mestinya mengagungkan keselamatan, kedamaian dan kesejahteraan. Peristiwa bom Bali berlanjut pada 12 Oktober 2005. Pertama yang diledakan di pantai kuta dan yang kedua yaitu Jimbaran. Selanjutnya pada 5 Agustus 2013 peledakan bom bunuh diri terjadi di hotel JW Mariott tahun 2013 yang dilakukan oleh Asmar Latin Sani. Ledakan tersebut telah menewasakan 12 orang dan melukai 150 orang. Bom bunuh diri selanjutnya yaitu yang terjadi di Sarinah yaitu pada 14 Januari 2016 lalu.

Salah satu contoh kasus bom Bali, dari temuan seorang film dokumenter freelance bernama Rudy Daniel Haryanto yang berhasil menyusup ke lapas Nusa Kambangan dan mewawancari

${ }^{19}$ Riza Sihbudi, "Islam, Radikalisme Dan Demokrasi," Republika, September 23, 2004, 23. 
Herlina dan Ahmad

empat orang perancang bom Bali 1, yaitu Imam Samudra, Ali Gufron, dan Amrozi, keempatnya adalah orang yang sehat jiwanya, bahkan cerdas. yang membuat mereka melakukan teror adalah idiologi untuk mendirikan Negara Islam Indonesia (NII), karena mereka percaya bahwa Indonesia harus menegakan hukum syariah sebagai satu-satunya cara untuk menghilangkan ketidak adilan dan meningkatkan kesejahteraan hidup umat Islam. Untuk tujuan itu mereka menyatakan perang terhadap pemerintah NKRI yang thagut (zalim), mereka menyatakan diri ikhlas mati dijalan Tuhan, sebagai mujahid dan yang sudah tewas dinyatakan mati syahid. ( kematian paling terhormat dalam pandangan Islam versi mereka). ${ }^{20}$

Menurut Azumardi Azra penyebab terorisme berdasarkan hasil dari pemahaman yang salah tentang konsep Jihad. Jihad sering diartikan sebagai perang suci, yang dipahami sebagai perang untuk melawan orang kafir. Melihat bahwa sistem pemerintah di Indonesia tidak sesuai dengan konsep mereka, yaitu konsep bahwa hukum politik, fikih, syariah, itu tidak dipisahkan oleh negara. Pimpinan negara harus tunduk kepada hukum Islam yang menggariskan cita-cita Islam untuk memberikan ketentuan perang kepada selain agama Islam. ${ }^{21}$

Ideologi Jihad semakin mengkristal menjadi ruh dalam gerakan sosial Islam pasca tragedi 11 september. Peristiwa bom bali 1 yang terjadi pada 12 oktober 2002 diebut-sebut sangat berkaitan dengan tragedi ini. Peristiwa bom Bali tidak saja telah mencoreng nama Bali sebagai kawasan yang dikenal aman oleh dunia Internasional, tetapi juga telah memasukan Indonesia kedalam sasaran war on global terorism, nama dari organisasi JI yang dikenal sebagai Jariangan Al- Qaeda di Asia Tenggara yang

${ }^{20}$ Azra, Formulasi Ajaran Islam Jihad, Khihafah, Dan Terorisme, 278.

${ }^{21}$ Azra, 345.

Vol. 3, No. 1 (2018) 
Pemabaman Keagamaan Pada Kasus Bom Bunub Diri

semakin hangat diperbincangkan sekaligus menjadi awal perkenalan kalangan radikal yang masuk ke Indonesia.

Bentuk penegakan hukum Islam tersebut mereka ambil karena pemahaman agama yang radikal. Dimana kekerasan atas nama agama sering dikaitkan dengan radikalisme agama. Walaupun keterkaitan tersebut tidak seluruhnya benar, namun demikian yang sering terungkap ke permukaan, bahwa radikalisme agama berkaitan dengan kekerasan agama. karena perilaku radikal adalah perilaku yang ditampilkan oleh orang-orang yang ingin melakukan perubahan dalam beberapa aspek yaitu sistem pemerintah, ketidak puasan terhadap hukum, dan memiliki motif tersendiri dengan melakukan seluruh aturan dan cara sampai ke akar-akarnya. Perubahan dimaksud adalah perubahan yang dilakukan secara mendasar dan cepat baik secra struktur maupun tidak terstruktur. Contoh terstruktur yaitu sesuai dengan cara yang sudah diatur mereka, secara tidak terstrukturnya sewaktu-waktu cara yang lain sekalipun berupa paksaan, mereka lakukan. Tujuannya adalah penjebolan terhadap status quo dan menggantinya dengan yang baru yang dianggapnya benar. Seringkali di dalam tindakannya menggunakan cara-cara yang keras, bahkan mampu melukai orang lain. atau disebut dengan kekerasan yang bercorak aktual.

Bentuk Kekerasan aktual adalah kekerasan yang nyata, transparan dan terjadi secara sungguh-sungguh, sedangkan kekerasan simbolik adalah kekerasan yang terjadi melalui simbolsimbol, bisa berupa bahasa di media lisan, tulisan maupun elektronik. Menurut Ahmad Tohari ada tiga corak kekerasan agama, yaitu: Pertama, kekerasan fisik yang terjadi antar umat beragama, seperti kekarasan pada Jemaat Ahmadiyah di kampus Mubarok. Kedua, kekerasan wacana yang biasanya terjadi di kalangan penganut salah satu agama, seperti wacana yang dikembangkan oleh Jaringan Islam Liberal yang menghasilkan 
Herlina dan Ahmad

kekerasan terhadapnya. Ketiga, kekerasan agama yang bercorak halus yang biasanya menggunakan medium seni atau sastra, ini dilakukan pada tayangan-tayangan perfilman, contohnya karya Panji Kusmin yang berjudul "Langit Makin Mendung", Salman Rushdi tentang "Satanic Verses".

Jika dilihat dari kepentingan politik, secara sederhana tujuan politik yang menjadi elemen utama kegiatan terorisme adalah kegiatan yang diarahkan pada perubahan kebijakan, cara pandang, model kepemimpinan, atau batas-batas wilayah (seperti yang terjadi di Israel). Keinginan untuk mendapatkan hasil dari perubahan itu bisa dilakukan secepatnya atau bisa juga menjadi titik titik akhir dari perjuangan yang panjang (the endpoints of a long struggle). Dalam konteks ini, beberapa kelompok teroris memang mengarahkan diri pada perjuangan yang panjang tadi untuk mencapai tujuan politik, tetapi ada juga organisasi yang langsung menunjukan atau melakukan tindak kekerasan (violence) sebagai hal yang sangat penting untuk menjatuhkan sebuah rezim atau mencapai tujuan yang diinginkan. ${ }^{22}$

Menurut Juliet Lodge, tujuan politik yang ingin dicapai telah memberikan justifikasi bagi berbagai organisasi terorisme untuk melakukan intimidasi yang bersifat paksaan, yaitu menghalalkan pembunuhan dan perilaku destruktif secara sistematis sebagai sarana untuk tujuan : menjadikan sasaran korban terutama masyarakat sipil sebagai sarana perang urat saraf yang menciptakan rasa takut dengan pesan yang sangat jelas. Ini biasanya didasarkan pada cara pandang idealistik utopis tentang perubahan yang sangat radikal atas cara pandang atau tatanan kehidupan dalam bermasyarakat maupun bernegara. ${ }^{23}$

${ }^{22}$ Jamhari Makruf, Memahami Terorisme, Dalam Jajang Jahroni, Konsep, Sejarah, Dan Model (Jakarta: Kencana, 2016), 12.

${ }^{23}$ Makruf, 13.

Vol. 3, No. 1 (2018) 
Pemahaman Keagamaan Pada Kasus Bom Bunub Diri

Spirit radikalisme yang didorong oleh teks-teks agama, sejauh bertujuan positif dan tidak menghancurkan sendi-sendi kemanusiaan, akan terjadi di mana saja ketika ada syarat-syarat sosial politik dan ekonomi mengandaikannya. Keragaman etnik dan agama saja bukan penyebab konflik sosial. Konflik sosial muncul manakala dalam suatu masyarakat timbul keresahan karena terdapat ketidakadilan dalam; Pertama, pembagian sumber daya ekonomi, dan Kedua partisipasi dalam pengambilan keputusan. Kedua hal tersebut dapat menyatukan sentimen-sentimen etnisitas dan agama. Ketika menggumpal, pecahlah konflik dari terpendamnya akumulasi kebencian dari kelompok yang merasa diperlakukan tidak adil kepada pihak yang dianggap bertanggung jawab. $^{24}$

\section{Bom Bunuh Diri Sebagai Penolakan Sistem Globalisasi}

Terjadinya bom bunuh diri juga sebagai bentuk penolakan terhadap globalisasi. Mereka menganggap bahwa sistem hukum di negara Indonesia adalah hasil dari pemikiran barat. juga memiliki sistem Thagut (berhala) dan tidak menggunakan hukum syariat Islam. Hal ini ditunjukan dengan doktrin-doktrin yang mereka diberikan sehingga terinternalisasi menjadi sebuah pegangan hidup dan diterima sebagai suatu kebenaran, kemudian disucikan dalam bentuk dogma, yang hanya kematian yang dapat memisahkan keyakian mereka.

Pemahaman keagamaan radikal yang dapat menggiring pelaku kekerasan / bunuh diri antara lain ${ }^{25}$ pemahaman bahwa :

1. Pemerintah republik Indonesia adalah pemerintah kafir.karena tidak menggunakan hukum Islam, aparat pemerintah itu

24 Azumardi Azra, "Sistem Siaga Dini Untuk Kerusuban Sosial II" (Jakarta, n.d.), 9-10.

25 Agus Ahmad Safei, Sosiologi Islam :Transformasi Sosial Berbasis Taubid (Jakarta: Simbiosa Rekatama Media, 2017), 117. 
Herlina dan Ahmad

"Thagut" atau setan yang harus diperangi dan halal dibunuh dan dirampas hartanya.

2. Upaya penegak hukum untuk menghentikan serangan Bom, dan menegakan hukum terhadap para pelaku tindak pidana terorisme merupakan sebuah serangan atau menzalimi umat Muslim.

3. Negara-Negara barat sekutu Amerika serikat merupakan "Thagut" yang dihalalkan darahnya karena dianggap telah menzalimi umat Islam di Irak dan Afghanistan. Maka keturunan barat dan ajaran yang bersumber dari barat harus ditiadakan.

4. Mereka harus hijrah meninggalkan kehidupan yang nyata seperti menikah, bertanggung jawab kepada keluarga. Bekerja dan hidup damai sebagai mahluk Tuhan, menuju kepada suatu kehidupan yang menginginkan kematian atau berkeyakinan adanya kebahagiaan setelah kematian ketika seseorang melakukan Bom bunuh diri.

5. Tidak pernah merasa melakukan kejahatan tetapi mengaggap dirinya sebagai pejuang yang harus melakukan berbagai tindakan atas perintah agama.

6. Siapapun, termauk orangtua, anak, dan istri akan dikafirkan apabila tidak sepaham.

7. Idiologi dapat dikembangkan dimana saja, termasuk dilembaga kemasyarakatan. Artinya mereka berkeyakinan paham yang dibawakannya sudah banyak orang yang mengikuti dan mereka akan berjuang untuk orang-orang atau jamaah mereka. ${ }^{26}$

\section{Kesimpulan}

Modernitas merupakan hasil dari globalisai, pengaruhnya kepada agama, bahwa agama akan dikalahkan oleh moderniatas, manusia akan lebih tergantung kepada hal yang berdasarkan nalar

${ }^{26}$ Azra, Formulasi Ajaran Islam Jihad, Khihafah, Dan Terorisme, 293.

Vol. 3, No. 1 (2018) 
Pemahaman Keagamaan Pada Kasus Bom Bunuh Diri

dan akal. Namun modernitas tersebut menuai pro dan kontra, sehingga memunculkan kelompok tertentu untuk mempertahankan eksistensi agama namun dengan cara yang fundamental, juga radikal, terdapat trutch claim kebenaran, dimana menganggap kebenaran adalah milik kelompok tertentu sementara kelompok lain salah, dan harus disingkirkan. Hal tersebut dibuktikan oleh kasus bom bunuh diri di Indonesia pertama kali terjadi pada peristiwa bom Bali pada 12 Oktober 2002, Bom Bali 2005, bom hotel JW Mariott Jakarta 2003, bom Kalimalang 2010, bom Mesjid Cirebon 2011, bom Sarinah 2016, hingga bom Kampung Melayu Jakarta 2017. Bom bunuh diri di Indonesia disebabkan oleh beberapa faktor, diantaranya sebagai hasil dari pemahaman mereka tentang konsep Jihad yang salah. Selain itu adanya sikap protes sebagai bentuk ungkapan kekecewaan terhadap pemerintah karena sistem hukum di Indonesia dianggap bukan hukum Islam yang mereka cita-citakan. Hukum Indonesia juga dipercaya sebagai hasil dari globalisasi yang datang dari pemahaman barat. Peran tokoh agama sangat diperlukan sebagai media penyelamat kesatuan negara NKRI (Negara Kesatuan Republik Indonesia).

\section{Daftar Pustaka}

Al- Munawar, Said Agil Husin. Fikib Hubungan Antar Agama. Ciputat: Ciputat press, 2005.

Al-Qardhawi, Yusuf. Islam Dan Globalisasi Dunia. Bandung: Pustaka Al-Kautsar, 2001.

Aslan, Adnan. Menyingkap Kebenaran: Pluralisme Agama Dalam Filsafat Islam Dan Kristen. Bandung: Alifya, 2004.

Azra, Azumardi. "Sistem Siaga Dini Untuk Kerusuban Sosial II." Jakarta, n.d. 
Herlina dan Ahmad

Azra, Azumardi dkk. Formulasi Ajaran Islam Jihad, Khihafah, Dan Terorisme. Jakarta: Mizan, 2016.

Baowollo, Robert B. Menggugat Tanggung Jawab Agama-Agama Abrahamik Bagi Perdamaian Dunia. Yogyakarta: Kanisius, 2010.

Beyer, Peter. Religion and Globalization, n.d.

Budiman, Arief. Teori-Teori Pembangunan Di Dunia Ketiga. Jakarta: Gramedia Pustaka Utama, 1994.

D, Hendropuspito. Sosiologi Agama. Yogyakarta: Kanisius, 2001.

Geertz, Clifford. Kebudayaan \& Agama. Yogyakarta: Kanisius, 1992.

Heriyanto, Husain. Menggali Nalar Saintifik Peradaban Islam. Jakarta: Mizan, 2011.

Hidayat, Komarudin. Passing Over: Melintas Batas Agama. Edited by Ahmad Gaus. Jakarta: Gramedia, 1998.

Kuntowijoyo. Muslim Tanpa Masjid. Bandung: Mizan, 2001.

Makruf, Jamhari. Memahami Terorisme, Dalam Jajang Jahroni , Konsep, Sejarah, Dan Model. Jakarta: Kencana, 2016.

Meuleman, Johan. Sikap Islam Terhadap Perkembangan Kontemporer Dalam Mukti Dkek, Agama Dalam Perkumpulan Masyarakat Modern. Yogyakarta: Tiara Wacana, 1998.

Pals, Daniel L. Dekonstruksi Tujuh Dekonstruksi Kebenaran. Yogyakarta: IRCiSoD, 2001.

Pardoyo. Sekularasi Dalam Polemik. Jakarta: Pustaka Utama Grafiti, 1993.

Permata. Metodologi Studi Agama, n.d.

Ritzer, George. Contemporary Sociological Theory. New York: McGraw Hill Companies Inc, 1985.

Vol. 3, No. 1 (2018) 
Pemahaman Keagamaan Pada Kasus Bom Bunuh Diri

Safei, Agus Ahmad. Sosiologi Islam:Transformasi Sosial Berbasis Taubid. Jakarta: Simbiosa Rekatama Media, 2017.

Sihbudi, Riza. "Islam, Radikalisme Dan Demokrasi." Republika, September 23, 2004.

Tehranian, Majid. "Globalization and Religious Resurgence: An Historical Perspektive” Vol. 97, no. No. 7 (2001).

Thaba, Abdul Azis. Islam Dan Negara Dalam Politik Orde Baru. Jakarta: Gema Insani Press, 1995.

Wajowasito. Kamus Bahasa Indonesia. Jakarta: Shinta Darma, 1972. 